\title{
PENGEMBANGAN MEDIA ISPRING PADA PEMBELAJARAN IPA BERBASIS STEM UNTUK MENGEMBANGKAN KREATIVITAS SISWA
}

\author{
Andini Rahmawati ${ }^{1}$, Retno Triwoelandari ${ }^{2}$, Muhammad Kholil Nawawi ${ }^{3}$ \\ ${ }_{1,2,3}$ Pendidikan Guru Madrasah Ibtidaiyah, Universitas Ibn Khaldun, \\ Jalan Sholeh Iskandar, Kedungbadak, Tanah Sereal, Bogor, Jawa Barat \\ 1e-mail: andini0603@gmail.com
}

\begin{tabular}{|c|c|c|c|c|c|}
\hline $\begin{array}{l}\text { Submitted } \\
2021-09-26\end{array}$ & $\begin{array}{c}\text { Accepted } \\
2021-11-24\end{array}$ & $\begin{array}{l}\text { Published } \\
2021-12-15\end{array}$ & open 0 Access & (c) (i) \& & asinta 3 \\
\hline
\end{tabular}

\begin{abstract}
Abstrak
Penelitian bertujuan mengembangkan media iSpring pada pembelajaran IPA berbasis STEM untuk mengembangkan kreativitas siswa. Metode penelitian menggunakan penelitian dan pengembangan atau research and development (R\&D). Model pengembangan yang digunakan adalah model ASSURE. Teknik analisis data yang digunakan yaitu analisis data kualitatif dan kuantitatif. Instrumen penelitian berupa angket dan lembar observasi. Penilaian produk berupa angket yang diberikan kepada ahli materi, bahasa, dan media. Uji coba produk yang dilakukan yaitu uji coba perorangan diberikan kepada 3 siswa, uji coba kelompok kecil diberikan kepada 8 siswa, dan uji coba kelompok besar diberikan kepada 15 siswa. Hasil penelitian diperoleh persentase kelayakan dari aspek materi dengan kategori valid, aspek bahasa dengan kategori valid, dan aspek media dengan kategori sangat valid. Berdasarkan hasil penelitian tersebut, disimpulkan bahwa media iSpring pada pembelajaran IPA berbasis STEM untuk mengembangkan kreativitas siswa layak untuk digunakan.
\end{abstract}

Kata Kunci: kreativitas; media iSpring; STEM.

\begin{abstract}
The research aimed to develop iSpring media on STEM-based IPA learning to develop student creativity. This research method used research and development $(R \& D)$. The development model used the ASSURE model. The data analysis techniques used qualitative and quantitative data analysis. Research instruments used questionnaires and observation sheets. Product assessment in the form of questionnaires given to material, language, and media experts. The individual trial was given to 3 students, the small group trial was given to 8 students, and the large group trial was given to 15 students. The results of the research obtained a percentage of eligibility from material aspects with valid categories, language aspects with valid categories, and media aspects with very valid categories. Based on the results, iSpring media on STEM-based science learning to develop students' creativity was feasible to use.
\end{abstract}

Keywords: creativity; iSpring media; STEM.

\section{PENDAHULUAN}

Ilmu pengetahuan dan teknologi (iptek) berkembang dengan cepat dan kompleks pada era globalisasi. Peran iptek yang semakin luas menjadikan setiap lembaga pendidikan bersaing dalam meningkatkan kualitas pendidikan. Sekolah 
Edukasi: Jurnal Pendidikan, Volume 19 Nomor 2 Tahun 2021

Pengembangan Media iSpring pada Pembelajaran IPA.......

Andini Rahmawati, Retno Triwoelandari, Muhammad Kholil Nawawi

Halaman 304-318

merupakan lembaga pendidikan yang terdampak oleh kecanggihan teknologi. Hal tersebut menjadikan setiap sekolah dituntut untuk menerapkan keterampilan abad ke-21 dalam kegiatan pembelajaran. Keterampilan abad ke-21 yang dibutuhkan dalam pembelajaran yaitu keterampilan berpikir kritis (critical thinking), kolaborasi (collaboration), komunikasi (communication), dan kreativitas (creativity) atau biasa disebut dengan 4C. Salah satu keterampilan abad ke-21 adalah kreativitas (creativity). Gallagher mengemukakan bahwa kreativitas adalah siklus psikologis yang dilakukan oleh individu sebagai gagasan atau terobosan baru dengan menggabungkan diantara keduanya yang pada akhirnya akan terhubung dengan dirinya (Rachmawati \& Kurniati, 2019).

Individu pada dasarnya memiliki potensi kreatif, tergantung cara individu tersebut mengembangkan serta menumbuhkan potensi kreatif. Permasalahan yang terjadi yaitu individu tidak menyadari potensi kreatif yang dimiliki dan tidak tahu cara mengembangkan potensi kreatif tersebut. Berdasarkan pengamatan peneliti pada saat praktik mengajar di salah satu madrasah ibtidaiyah (MI) di kota Bogor, terlihat bahwa siswa kurang mengemukakan gagasan atau ide saat kegiatan pembelajaran berlangsung. Hasil penelitian terdahulu menunjukkan bahwa kreativitas dan hasil belajar siswa rendah karena masih ada siswa yang tidak berani mengungkapkan pemikiran yang inovatif dan tidak adanya tempat untuk berkomunikasi seperti yang ditunjukkan imajinasi siswa (Natty et al., 2019).

Peran guru dalam kegiatan pembelajaran selain menjadi pendidik yaitu sebagai fasilitator dan motivator. Guru tidak hanya mempersiapkan bahan ajar seperti materi pembelajaran saja, tetapi guru dituntut merancang media pembelajaran. Media pembelajaran dianggap sebagai apapun yang dapat diteruskan atau memberikan pesan dari sumber dengan cara yang diatur dan sesuai untuk membangun lingkungan yang kondusif dimana penerima manfaat dapat menyelesaikan latihan pembelajaran secara memadai dan produktif (Susanto \& Akmal, 2019) dan merupakan salah satu faktor yang memengaruhi hasil belajar siswa/peserta didik (Setiawan, 2021; Budiman \& Nurbani, 2019; Arpan et al., 2018; Budiman, 2016). Guru mempunyai peluang untuk menciptakan media pembelajaran yang inovatif dengan memanfaatkan kecanggihan teknologi, salah 
satunya menggunakan aplikasi iSpring Presenter. iSpring Presenter adalah alat yang mengubah dokumen pertunjukan menjadi struktur garis dan struktur SCORM/AICC yang merupakan bingkai pada pembelajaran e-learning dalam learning management system atau LSM (Alfiandra \& Mulyadi, 2016).

Berdasarkan hasil wawancara peneliti terhadap guru Sekolah Dasar Islam Terpadu (SDIT) Khoiru Ummah diketahui bahwa guru masih belum signifikan dalam menerapkan media pembelajaran di sekolah, khususnya pada media iSpring. Kegiatan belajar hanya menggunakan buku pegangan guru dan siswa. Hal tersebut menjadikan proses pembelajaran di kelas tidak melibatkan siswa secara aktif dan siswa cenderung kurang mengasah keterampilan kreativitas dalam mengemukakan ide atau gagasan.

Media iSpring Suite 8 digunakan untuk menunjang pembelajaran IPA agar siswa dapat mengembangkan kreativitas. Materi pada pembelajaran IPA terdapat kegiatan-kegiatan aktif yang akan merangsang siswa untuk mengembangkan potensi kreatif. Kreativitas dapat dikembangkan dengan mengimplementasikan science, technology, engineering, and mathematics (STEM) dalam pembelajaran IPA. STEM secara tegas diidentifikasi satu sama lain, sains membutuhkan matematika untuk alat dalam menangani informasi, sedangkan inovasi dan perancangan adalah pemanfaatan sains (Wibowo, 2018). IPA berbasis STEM memengaruhi hasil pembelajaran lebih unggul daripada hasil pembelajaran siswa pada pelajaran lain (Suwarma et al., 2015). Belajar dengan menerapkan STEM memberikan manfaat dalam kehidupan di masa depan siswa, karena sebelumnya sudah memiliki pengalaman dalam memecahkan suatu permasalahan di kehidupan nyata (Sukmana, 2017). Hasil penelitian terdahulu menunjukkan bahwa pembelajaran STEM meningkatkan kreativitas karena anak-anak ikut serta dalam menjelajahi lingkungan secara luas (Nurjanah, 2020).

Pembelajaran IPA berbasis STEM menggunakan media iSpring dapat mengembangkan kreativitas siswa dan materi yang disampaikan terlihat akan lebih menarik. Hal tersebut untuk memenuhi kebutuhan siswa, media iSpring tepat sebagai penunjang proses pembelajaran. Berdasarkan permasalahan yang 
Edukasi: Jurnal Pendidikan, Volume 19 Nomor 2 Tahun 2021

Pengembangan Media iSpring pada Pembelajaran IPA.......

Andini Rahmawati, Retno Triwoelandari, Muhammad Kholil Nawawi

Halaman 304-318

telah diuraikan, maka tujuan penelitian adalah mengembangkan media iSpring pada pembelajaran IPA berbasis STEM untuk mengembangkan kreativitas siswa.

\section{METODE}

Metode penelitian menggunakan penelitian dan pengembangan atau research and development $(\mathrm{R} \& \mathrm{D})$. Penelitian dilakukan di SDIT Khoiru Ummah Leuwisadeng Kabupaten Bogor. Subjek penelitian pengembangan adalah siswa kelas IV SDIT Khoiru Ummah. Penelitian pengembangan media iSpring pada pembelajaran IPA berbasis STEM menggunakan model pengembangan ASSURE dengan tahapan: analyze learners; state standard and objectives; select strategies, technology, media, and materials; utilize strategies, technology, media and materials; require learner participation; dan evaluated.

Tahap pertama adalah analyze learners. Peneliti menganalisis siswa kelas IV SDIT Khoiru Ummah dengan cara pengamatan (observasi) dan wawancara ke guru kelas IV. Hal tersebut bertujuan untuk mengetahui karakteristik umum, kompetensi siswa, serta gaya belajar siswa. Tahap kedua adalah state standard and objectives. Kegiatan yang dilakukan adalah menyusun tujuan pembelajaran yang ingin dicapai sesuai dengan analiasis kebutuhan. Tahap ketiga adalah select strategies, technology, media, and materials. Peneliti memilih strategi, teknologi, media, dan materi dengan pembelajaran IPA berbasis STEM yang akan dikemas dalam media iSpring. Produk divalidasi oleh 3 ahli, yaitu ahli materi, bahasa, dan media. Hal tersebut bertujuan untuk menemukan tingkat kelayakan media iSpring. Kriteria penilaian dilihat dari beberapa aspek. Penilaian ahli materi dilihat aspek kelayakan isi dan penyajian. Penilaian ahli bahasa dilihat aspek kelayakan bahasa dan penilaian kontekstual. Penilaian ahli media dilihat dari aspek desain dan tampilan media. Pedoman kriteria penilaian tersebut mengacu pada Badan Standar Nasional Pendidikan (BSNP).

Tahap keempat adalah utilize strategies, technology, media and materials. Peneliti mengujicobakan produk yang sudah divalidasi para ahli. Produk tersebut diujicobakan dalam 3 tahap, yaitu uji coba perorangan, uji coba kelompok kecil, dan uji coba kelompok besar. Tahap kelima adalah require learner participation. 
Peneliti melibatkan partisipasi siswa pada kegiatan pembelajaran. Tahap keenam adalah evaluated. Peneliti menilai kelayakan dan keefektifan produk berdasarkan data yang didapatkan. Pedoman penilaian mengacu pada kriteria interpretasi skor menurut Riduwan (Hildayatni et al., 2019) seperti terlihat di Tabel 1.

Tabel 1 Kriteria Interpretasi Skor

\begin{tabular}{ccc}
\hline Persentase & Kualifikasi & Kriteria Kelayakan \\
\hline $81 \%-100 \%$ & SangatValid & Tidak Revisi \\
$61 \%-80 \%$ & Valid & Tidak Revisi \\
$41 \%-60 \%$ & Cukup Valid & Perlu Revisi \\
$21 \%-40 \%$ & Kurang Valid & Revisi \\
$0 \%-20 \%$ & Sangat Kurang Valid & Revisi Total \\
\hline
\end{tabular}

Pengumpulan data menggunakan lembar pengamatan dan kuesioner (angket). Teknik analisis data menggunakan analisis deskriptif kualitatif dan kuantitatif. Analisis deskriptif kualitatif menggunakan rumus (1).

$$
\text { Persentase }=\frac{\text { Perolehan skor }}{\text { Skor maksimal }} \times 100 \%
$$

Analisis data kuantitatif digunakan untuk menghitung hasil pengamatan keterampilan kreativitas siswa. Hasil pengamatan dapat dilihat dari lembar observasi yang terdiri dari 7 indikator pencapaian kreativitas. Indikator pencapaian kreativitas terlihat di Tabel 2.

Tabel 2 Indikator Pencapaian Kreativitas

\begin{tabular}{llc}
\hline Keterampilan & \multicolumn{1}{c}{ Indikator Pencapaian Kreativitas } & $\begin{array}{c}\text { Jumlah } \\
\text { Butir }\end{array}$ \\
\hline & $\begin{array}{l}\text { Mengemukakan gagasan/ide, pertanyaan, dan } \\
\text { jawaban. }\end{array}$ & 3 \\
$\begin{array}{l}\text { Mencari banyak altaernatif dalam memecahkan } \\
\text { masalah. }\end{array}$ & 1 \\
Kemampuan menghasilkan beberapa ide, \\
jawaban, dan pertanyaan yang beragam. \\
$\begin{array}{l}\text { Melihat permasalahan dari sisi yang berbeda. } \\
\text { Mampu mengungkapkan hal-hal yang unik dan } \\
\text { luar biasa. } \\
\text { Mampu mengembangkan suatu produk. } \\
\text { Memperinci detail suatu objek. }\end{array}$
\end{tabular}


Edukasi: Jurnal Pendidikan, Volume 19 Nomor 2 Tahun 2021

Pengembangan Media iSpring pada Pembelajaran IPA....

Andini Rahmawati, Retno Triwoelandari, Muhammad Kholil Nawawi

Halaman 304-318

Penilaian media iSpring dilakukan oleh siswa dalam bentuk angket dengan 11 pertanyaan. Penilaian tersebut sesuai dengan tahap pengujian media, yaitu uji perorangan, kelompok kecil, dan kelompok besar. Respons masing-masing pertanyaan terwujud dalam skor angka 1 sampai 4. Skor setiap pertanyaan dijumlahkan dan diperhitungkan persentase skor. Nilai persentase dikonversi menjadi tingkat kelayakan sesuai Tabel 1. Indikator penilaian respons siswa pada media iSpring dapat dilihat di Tabel 3.

Tabel 3 Indikator Penilaian Respons Siswa

\begin{tabular}{|c|c|}
\hline $\begin{array}{l}\text { Indikator } \\
\text { Penilaian }\end{array}$ & Butir Penilaian \\
\hline Ketertarikan & $\begin{array}{l}\text { Siswa tertarik dengan tampilan media yang dikembangkan. } \\
\text { Siswa jadi lebih ingin belajar dengan menggunakan media } \\
\text { yang dikembangkan. } \\
\text { Siswa lebih paham materi pelajaran menggunakan media } \\
\text { yang dikembangkan. } \\
\text { Siswa tidak bosan belajar menggunakan media yang } \\
\text { dikembangkan. }\end{array}$ \\
\hline Materi & $\begin{array}{l}\text { Siswa senang belajar menggunakan media yang } \\
\text { dikembangkan. } \\
\text { Materi yang disampaikan saling terkait dengan kehidupan } \\
\text { sehari-hari siswa. } \\
\text { Materi yang dijelaskan membantu siswa dalam } \\
\text { mengembangkan keterampilan IPA. } \\
\text { Siswa jadi lebih mudah memahami materi dengan adanya } \\
\text { gambar pada media yang dikembangkan. }\end{array}$ \\
\hline Bahasa & $\begin{array}{l}\text { Siswa mudah mengerti dengan bahasa sederhana yang } \\
\text { dipaparkan pada media yang dikembangkan. } \\
\text { Siswa lebih mudah dalam membaca materi dengan huruf } \\
\text { yang dipaparkan pada media yang dikembangkan. } \\
\text { Siswa lebih mudah memahami materi pada setiap kalimat } \\
\text { yang digunakan dalam media yang dikembangkan. }\end{array}$ \\
\hline
\end{tabular}

Data dianilisis menggunakan SPSS 25 for Windows. Data terlebih dahulu dianalisis uji normalitas dan homogenitasnya berdasarkan kriteria penilaian, yaitu nilai signifikan ( $p$-value) lebih rendah dari 0,05. Hal tersebut untuk menguji hasil posttest antara kelas eksperimen dan kelas kontrol. Hasil pengamatan keterampilan kreativitas siswa pada uji coba media iSpring pembelajaran IPA berbasis STEM dianalisis melalui uji-t, yaitu paired samples t-test untuk diuji hasil rata-rata pretest dan posttest serta independent samples t-test untuk diuji 
perbandingan rata-rata pretest pada kelas eksperimen (kelas IV B) dan kelas kontrol (kelas IV A). Keefektifan produk iSpring dinilai dengan melihat adanya perbedaan hasil rata-rata pretest yang lebih tinggi dari posttest pada kelas yang mendapatkan perlakuan menggunakan media iSpring.

\section{HASIL DAN PEMBAHASAN}

Tahap pertama dari langkah R\&D adalah analyze learners. Hasil observasi dan wawancara yang didapat yaitu sekolah mempunyai sarana yang cukup memenuhi untuk menunjang kegiatan pembelajaran, seperti ruang kelas yang cukup luas serta fasilitas yang mendukung untuk mengembangkan media. Pemanfaatan media pembelajaran masih belum diterapkan di sekolah tersebut. Keterampilan kreativitas yang dimiliki oleh siswa kelas IV dalam menjawab pertanyaan dan mengemukakan gagasan ada yang belum terlihat dan ada yang sudah terlihat karena minimnya melakukan kegiatan-kegiatan kreatif. Gaya belajar yang sering digunakan untuk siswa kelas IV yaitu belajar berkelompok karena dengan belajar berkelompok akan terlihat siswa yang aktif dan tidak aktif.

Tahap kedua adalah state standards and objective. Tema yang dipilih adalah buku kelas 4 tema 2 yaitu Selalu Berhemat Energi dengan subtema 1 yaitu Sumber Energi. Tujuan pembelajaran yang ditetapkan yaitu siswa dapat mengidentifikasi pemanfaatan sumber energi matahari, angin, dan air serta membuat rancangan alat sederhana pemanfaatan sumber energi matahari, angin, dan air dalam kehidupan sehari-hari. Tujuan pembelajaran tersebut dipilih karena dapat mengembangkan kreativitas siswa. Tahap ketiga adalah select strategies, technology, media, and materials. Produk yang sudah dikemas dalam media iSpring, selanjutnya divalidasi 3 ahli yaitu ahli materi, bahasa, dan media. Hasil kelayakan media iSpring terlihat di Tabel 4.

Tabel 4 Hasil Penilaian Media iSpring

\begin{tabular}{ccc}
\hline Validator & Presentase & Keterangan \\
\hline Ahli Materi & $77,4 \%$ & Valid \\
Ahli Bahasa & $80,5 \%$ & Valid \\
Ahli Media & $97,7 \%$ & Sangat Valid \\
\hline
\end{tabular}


Edukasi: Jurnal Pendidikan, Volume 19 Nomor 2 Tahun 2021

Pengembangan Media iSpring pada Pembelajaran IPA

Andini Rahmawati, Retno Triwoelandari, Muhammad Kholil Nawawi

Halaman 304-318

Saran dan komentar dari ahli materi yaitu perkaya contoh pemanfaatan sumber energi dan dibuat lebih spesifik. Kualitas media dapat ditentukan pada informasi yang diberikan tidak berlebihan serta tidak kurang (Mais, 2016). Sebelumnya terdapat 3 contoh pemanfaatan sumber energi dan tidak spesifik, setelah diperbaiki contoh sudah bertambah dan spesifik, terlihat di Gambar 1.

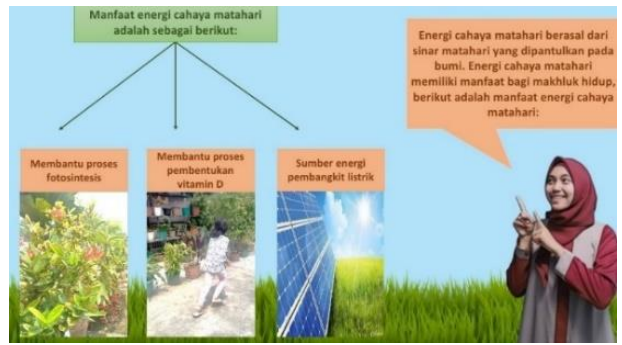

(a)

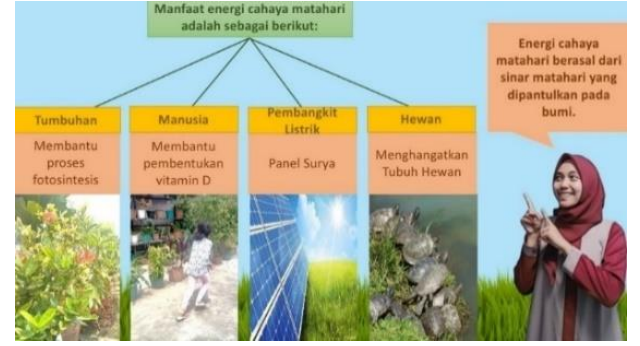

(b)

Gambari 1 Perbaikan Slide dengan Penambahan Contoh Pemanfaatan Sumber Energi: (a) Sebelum Perbaikan (b) Sesudah Perbaikan

Saran dan komentar dari ahli bahasa adalah perbaiki ukuran font. Kebutuhan siswa diperlukan dalam menggunakan media pembelajaran (Amka, 2018). Font sebelumnya ukuran 20pt setelah diperbaiki menjadi 22pt. Perbaikan dapat dilihat di Gambar 2.

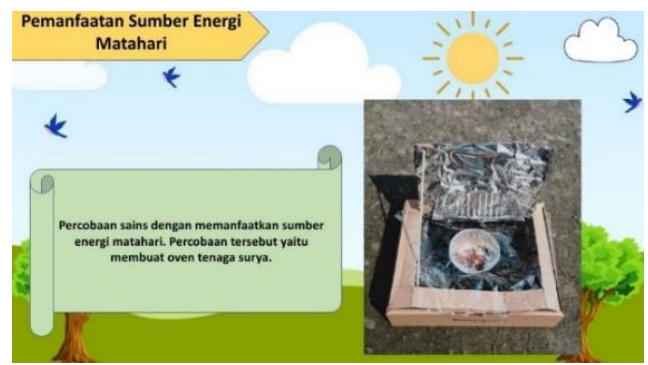

(a)

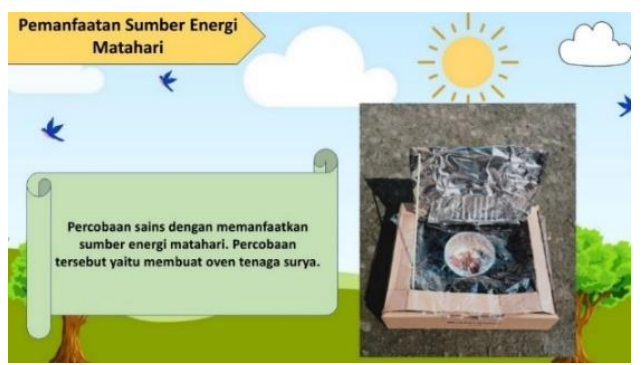

(b)

Gambar 2 Perbaikan pada Ukuran Font (a) Sebelum Perbaikan (b) Sesudah Perbaikan

Saran dan komentar dari ahli media adalah gambar perlu disesuaikan dengan penjelasan. Penggunaan gambar harus sesuai dengan perkembangan siswa serta tujuan dalam pembelajaran (Mirnawati, 2020). Sebelumnya gambar air belum sesuai, setelah diperbaiki gambar air sudah sesuai dan dapat dilihat di Gambar 3. 


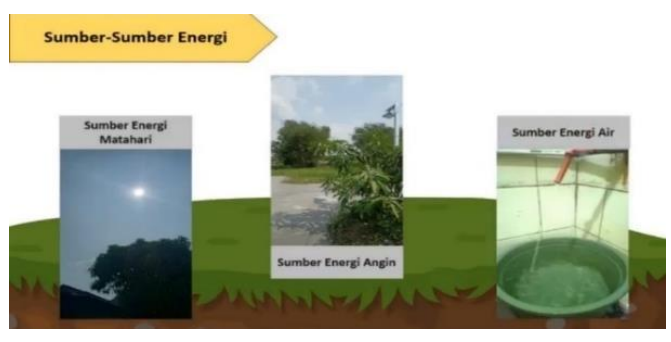

(a)

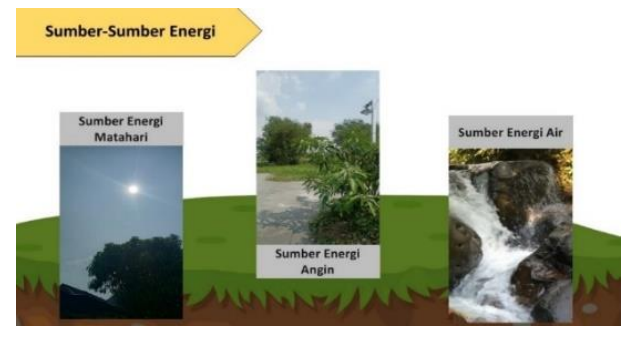

(b)

\section{Gambar 3 Perbaikan pada Gambar Sumber Energi} (a) Sebelum Perbaikan (b) Sesudah Perbaikan

Tahap keempat adalah utilize strategies, technology, media and materials. Media iSpring diujikan pada proses pembelajaran. Siswa belajar dengan menggunakan media iSpring dengan pembahasan tentang Sumber Energi. Media iSpring yang ditampilkan berupa video pembelajaran serta terdapat video tentang percobaan eksperimen yang nantinya akan dipraktikkan oleh siswa. Tahap kelima adalah require learner and participation. Hasil dari kegiatan dengan menggunakan media iSpring yaitu siswa berani mengungkapkan gagasan/ide, siswa senang mengajukan pertanyaan atau memberikan jawaban, serta siswa berpartisipasi aktif dalam kegiatan pembelajaran. Tahap keenam adalah evaluated. Hasil penilaian respons siswa dalam tahapan uji perorangan, uji kelompok kecil, dan uji kelompok besar. Hasilnya dapat dilihat di Tabel 5.

\section{Tabel 5 Hasil Penilaian Respons Siswa}

\begin{tabular}{ccc}
\hline Tahap Uji & Persentase & Keterangan \\
\hline Perorangan & $90,9 \%$ & Sangat Baik \\
Kelompok Kecil & $86,6 \%$ & Sangat Baik \\
Kelompok Besar & $89,4 \%$ & Sangat Baik \\
\hline
\end{tabular}

Peneliti menguji normalitas dan homogenitas data sebelum uji-t. Hasil pengujian normalitas diperoleh nilai sig (2-tailed) 0,200 lebih tinggi dari 0,05 dan hasil pengujian homogenitas diperoleh hasil sig 0,409 lebih tinggi dari 0,05. Hal tersebut berarti data berdistribusi normal dan bersifat homogen. Data yang didapat bersifat normal dan homogen berarti data tersebut memperoleh nilai Sig. (2-tailed) lebih tinggi dari 0,05 (Fikri, 2016). Hasil analisis data menggunakan uji-t melalui nilai pretest dan posttestt kelas eksperimen dan kontrol dapat dilihat di Tabel 6. 
Edukasi: Jurnal Pendidikan, Volume 19 Nomor 2 Tahun 2021

Pengembangan Media iSpring pada Pembelajaran IPA.......

Andini Rahmawati, Retno Triwoelandari, Muhammad Kholil Nawawi

Halaman 304-318

\begin{tabular}{ccc}
\hline Kelas & Pretest & Posttest \\
\hline Eksperimen & 19,3 & 27,4 \\
Kontrol & 16,3 & 21,5 \\
\hline
\end{tabular}

Hasil uji-t menggunakan paired samples test kelas eksperimen dan kontrol dapat dilihat di Tabel 7.

Tabel 7 Paired Samples Test Kelas Eksperimen dan Kontrol

\begin{tabular}{cccc}
\hline Kelas & Mean & T & Sig (2-tailed) \\
\hline Eksperimen & $-8,13333$ & $-27,989$ & 0,000 \\
Kontrol & $-5,20000$ & $-12,420$ & 0,000 \\
\hline
\end{tabular}

Berdasarkan Tabel 7, terlihat bahwa perbedaan rata-rata pretest dan posttest menunjukkan tanda (-) yang berarti hasil posttest lebih tinggi dari hasil pretest. Hasil tersebut menunjukkan adanya perbedaan hasil setelah menggunakan media iSpring. Tanda (-) dalam uji paired samples test berarti rata-rata hasil posttest lebih tinggi dari hasil pretest (Sakinah et al., 2020).

Hasil perbedaan rata-rata kelas eksperimen dan kontrol tersebut kemudian dilakukan anilisis dengan independent sample t-test. Analisis independent sample t-test diperoleh hasil rata-rata sebesar 5,86667 dengan sig (2-tailed) 0,000. Hal tersebut berarti terdapat perbedaan yang signifikan antara hasil pengamatan kelas eksperimen dan hasil pengamatan kelas kontrol dalam pembelajaran IPA berbasis STEM, sebab sig (2-tailed) lebih rendah daripada 0,05. Hal tersebut menunjukkan adanya pengembangan kreativitas dengan menerapkan media iSpring dalam pembelajaran IPA berbasis STEM. Efektivitas produk dikembangkan dengan melihat uji pemanfaatan media iSpring dalam mengembangkan kreativitas siswa. Uji tersebut menggunakan produk pembelajaran IPA berbasis STEM dengan tema Selalu Berhemat Energi. Pengamatan tersebut dilihat dari situasi saat menggunakan produk dan sebelum menggunakan produk.

Gambar 4 memperlihatkan adanya perbedaan hasil pretest dan posttest. Hasil tersebut menunjukkan adanya pengembangan kreativitas pada saat pembelajaran. Kesimpulan dari hasil penelitian adalah iSpring dalam pembelajaran IPA berbasis STEM efektif mengembangkan kreativitas siswa. 


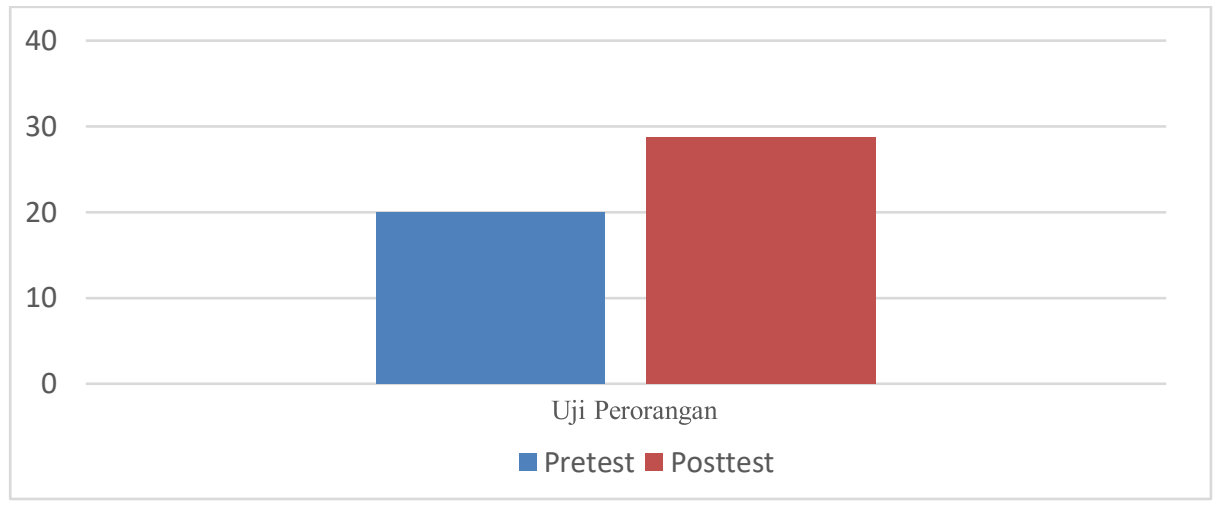

Gambar 4 Efektivitas Uji Perorangan

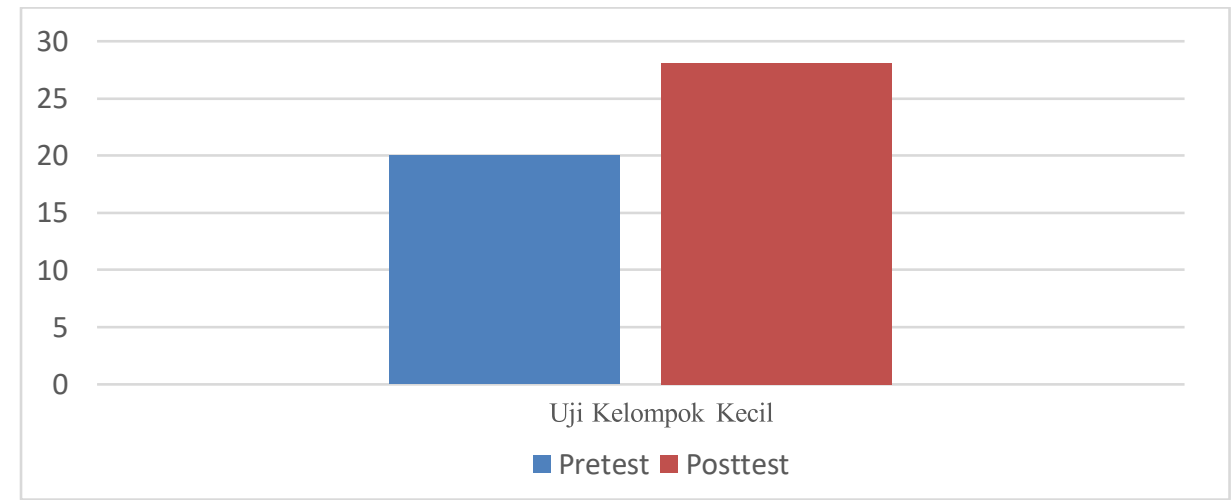

Gambar 5 Efektivitas Uji Kelompok Kecil

Gambar 5 memperlihatkan perbedaan hasil antara pretest dan posttest. Hasil tersebut menunjukkan adanya pengembangan kreativitas pada saat pembelajaran. Kesimpulan dari hasil tersebut media iSpring dalam pembelajaran IPA berbasis STEM efektif mengembangkan kreativitas siswa.

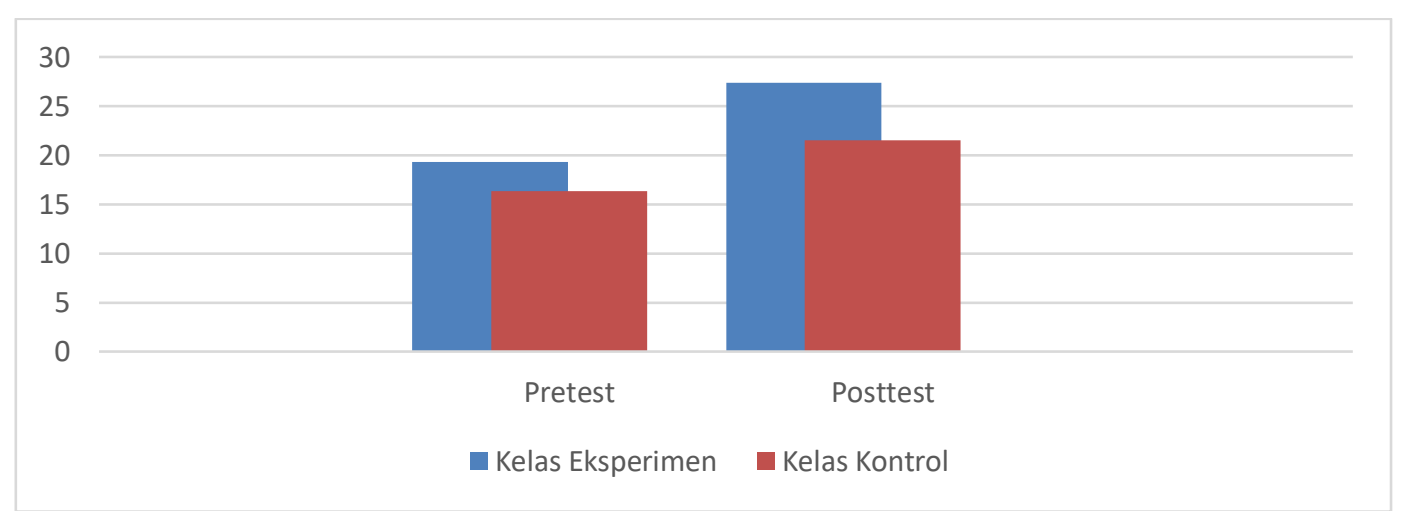

\section{Gambar 6 Efektivitas Uji Kelompok Besar}


Edukasi: Jurnal Pendidikan, Volume 19 Nomor 2 Tahun 2021

Pengembangan Media iSpring pada Pembelajaran IPA....

Andini Rahmawati, Retno Triwoelandari, Muhammad Kholil Nawawi

Halaman 304-318

Gambar 6 memperlihatkan adanya perbedaan hasil antara pretest dan posttest kelas eksperimen dan kelas kontrol. Hasil posttest menunjukkan kelas eksperimen lebih tinggi dari kelas kontrol karena kelas eksperimen mendapatkan perlakuan menggunakan media iSpring. Hal tersebut menunjukkan adanya pengembangan kreativitas pada saat pembelajaran dan media iSpring efektif dalam pembelajaran IPA berbasis STEM.

Media pembelajaran menjadi suatu kebutuhan bagi siswa dalam pembelajaran dan dimanfaatkan guru sebagai penunjang pembelajaran. Media pembelajaran sebagai alat penyampaian materi pelajaran serta menjadikan siswa aktif dalam proses pembelajaran sehingga memengaruhi hasil belajar (Arpan \& Sadikin, 2020; Permana \& Budiman, 2020; Irwandani \& Juariyah, 2016). Penggunaan media pembelajaran yang menarik seperti media iSpring akan memengaruhi keterampilan siswa termasuk keterampilan kreativitas, namun semua kembali sesuai dengan diri masing-masing siswa. Siswa memiliki sudut pandang yang berbeda pada kreativitasnya dan dengan melakukan kegiatan yang aktif, kreativitas siswa berkembang sesuai diri masing-masing (Nurjanah, 2020). Hasil penilaian para ahli dan respons siswa menunjukkan bahwa media iSpring layak untuk digunakan karena memiliki tingkat kelayakan dengan kategori sangat baik. Media yang bekualifikasi baik, layak untuk digunakan dan diaplikasikan pada pembelajaran di sekolah (Sakinah et al., 2020).

Berdasarkan Gambar 4, 5, dan 6, terdapat perbedaan hasil pretest dan posttest yang berarti adanya pengembangan kreativitas siswa saat pembelajaran. Hal tersebut menjadikan media iSpring efektif dalam mengembangkan kreativitas siswa. Keefektifan media iSpring memudahkan guru dalam memberikan materi pembelajaran, siswa menjadi tidak mudah bosan serta membantu siswa dalam mengembangkan kreativitas pada pembelajaran IPA berbasis STEM. Media pembelajaran adalah media inovatif digunakan dalam menyampaikan topik kepada siswa sehingga proses pengajaran dan pembelajaran lebih sukses, mahir, dan menyenangkan (Wibawanto, 2017). Pengembangkan media iSpring pembelajaran IPA di tingkat sekolah dasar mendapatkan hasil dengan kualifikasi 
sangat baik sehingga media iSpring baik untuk diimplementasikan pada pembelajaran IPA (Yuniasih et al., 2018).

\section{SIMPULAN}

Berdasarkan hasil penelitian, produk media iSpring yang dikembangkan valid dalam penilaian validator dan dikategorikan sangat baik dalam penilaian respons siswa sehingga disimpulkan bahwa produk media pembelajaran iSpring layak dan efektif untuk diimplementasikan di sekolah serta dapat mengembangkan kreativitas siswa.

\section{DAFTAR PUSTAKA}

Alfiandra \& Mulyadi, M. (2016). Pengembangan Produk Pembelajaran melalui Media iSpring pada Mata Pelajaran Pendidikan Pancasila dan Kewarganegaraan (PPKn) di SMK Negeri 2 Palembang. Jurnal Bhinneka Tunggal Ika, 3(1), 1-11.

Amka, H. (2018). Media Pembelajaran Inklusi. Sidoarjo: Nizmala Learning.

Arpan, M., \& Sadikin, S. (2020). Media Pembelajaran Interaktif Perangkat Keras Komputer. INVOTEK: Jurnal Inovasi Vokasional dan Teknologi, 20(2), 4350. https://doi.org/10.24036/invotek.v20i2.741.

Arpan, M., Budiman, R. D. A., \& Verawardina, U. (2018). Prototype Media Pembelajaran Pengenalan Hardware Jaringan Komputer Berbasis Augmented Reality. Prosiding Seminar Nasional II APPPI NTB 2018.

Budiman, R. (2016). Developing Learning Media Based on Augmented Reality (AR) to Improve Learning Motivation. JETL (Journal of Education, $\begin{array}{llll}\text { Teaching } \quad \text { and } \quad \text { Learning), } & \text { 89-94. }\end{array}$ http://dx.doi.org/10.26737/jetl.v1i2.45.

Budiman, R. D. A., \& Nurbani, N. (2019). Pengembangan Media Pembelajaran Pengenalan Sistem Operasi Berbasis Android. Edukasi: Jurnal Pendidikan, 17(2), 183-197. http://dx.doi.org/10.31571/edukasi.v17i2.1305.

Fikri, M. (2016). Cara Mudah Membuat Makalah, Skripsi dan Tesis. Bogor: Arabasta Media. 
Edukasi: Jurnal Pendidikan, Volume 19 Nomor 2 Tahun 2021

Pengembangan Media iSpring pada Pembelajaran IPA

Andini Rahmawati, Retno Triwoelandari, Muhammad Kholil Nawawi

Halaman 304-318

Hildayatni, D., Triwoelandari, R., \& Hakiem, H. (2019). Kelayakan Modul Pembelajaran IPA Terintegrasi Nilai Agama untuk Mengembangkan Karakter Rasa Ingin Tahu. JMIE: Journal of Madrasah Ibtidaiyah, 3(2), 203-218.

Irwandani, I., \& Juariyah, S. (2016). Pengembangan Media Pembelajaran Berupa Komik Fisika Berbantuan Sosial Media Instagram sebagai Alternatif Pembelajaran. Jurnal Ilmiah Pendidikan Fisika Al-Biruni, 5(1), 33-42. https://doi.org/10.24042/jpifalbiruni.v5i1.103.

Mais, A. (2016). Media Pembelajaran Anak Berkebutuhan Khusus. Jember: CV Pustaka Abadi.

Mirnawati. (2020). Penggunaan Media Gambar dalam Pembelajaran untuk Meningkatkan Minat Baca Siswa. Jurnal Didaktika, 9(1), 98-112. https://jurnaldidaktika.org/contents/article/download/14/12.

Natty, R. A., Kristin, F., \& Anugraheni, I. (2019). Peningkatkan Kreativitas dan Hasil Belajar Siswa melalui Model Pembelajaran Project Based Learning di Sekolah Dasar. Jurnal Basicedu, 3(4), 1082-1092. https://doi.org/10.31004/basicedu.v3i4.262.

Nurjanah, N. E. (2020). Pembelajaran STEM Berbasis Loose Parts untuk Meningkatkan Kreativitas Anak Usia Dini. Jurnal AUDI: Jurnal Ilmiah Kajian Ilmu Anak dan Media Informasi PUD, 1(1), 19-31.

Permana, R., \& Budiman, R. D. A. (2020). Pengembangan Media Pembelajaran IP Traffic Work Berbasis Augmented Reality. CYBERNETICS, 4(01), 4149. http://dx.doi.org/10.29406/cbn.v4i01.1970.

Rachmawati, Y., \& Kurniati. E. (2019). Strategi Pengembangan Kreativitas pada Anak Usia Taman Kanak-Kanak. Jakarta: Prenadamedia Group.

Ristiani, S. M., Triwoelandari, R., \& Yono, Y. (2020). Pengembangan Media Pembelajaran Lectora Inspire Versi 12 pada Mata Pelajaran IPA Berbasis STEM untuk Menumbuhkan Karakter Kreatif Siswa. Jurnal Basicedu, 5(1), 30-40. https://doi.org/10.31004/basicedu.v5i1.613.

Sakinah, K., Triwoelandari, R., \& Fahri, M. (2020). Pengembangan Media Pembelajaran iSpring untuk Meningkatkan Karakter Rasa Ingin Tahu Siswa 
pada Pembelajaran IPA Berbasis STEM. Journal of Chemical Information and Modeling, 3(2), 118-131. https://doi.org/10.32478/al-mudarris.v.

Setiawan, W. (2021). Pengembangan Media Pembelajaran Berbasis Android dengan App Inventor pada Materi Perangkat Lunak Pengolah Kata. JUWARA: Jurnal Wawasan dan Aksara, 1(1), 37-46.

Sukmana, R. W. (2017). Pendekatan Science, Technology, Engineering and Mathematics (STEM) sebagai Alternatif dalam Mengembangkan Minat Belajar Peserta Didik Sekolah Dasar. Pendas: Jurnal Ilmiah Pendidikan Dasar, 2(2), 191-199.

Susanto, H., \& Akmal, H. (2019). Media Pembelajaran Sejarah Era Teknologi Informasi: (Konsep Dasar, Prinsip Aplikatif, dan Perancangannya). Banjarmasin: Penerbit Program Studi Pendidikan Sejarah.

Suwarma, I. R., Astuti, P., \& Endah, E. N. (2015). "Balloon Powered Car" sebagai Media Pembelajaran IPA Berbasis STEM (Science, Technology, Engineering, and Mathematics). Prosiding Simposium Nasional Inovasi dan Pembelajaran Sains 2015.

Wibawanto, W. (2017). Desain dan Pemrograman Multimedia Pembelajaran Interaktif. Jember: Penerbit Cerdas Ulet Kreatif.

Wibowo, I. G. A. W. (2018). Peningkatan Keterampilan Ilmiah Peserta Didik dalam Pembelajaran Fisika melalui Penerapan Pendekatan STEM dan ELearning. Journal of Education Action Research, 2(4), 315. https://doi.org/10.23887/jear.v2i4.16321.

Yuniasih, N., Aini, R. N., \& Widowati, R. (2018). Pengembangan Media Interaktif Berbasis iSpring Materi Sistem Pencernaan. Jurnal Inspirasi Pendidikan, 8(2), 85-94. https://doi.org/10.21067/jip.v8i2.2647. 